\title{
Comparison and Optimization of Circulation Modes of Fresh Agricultural Products Based on System Dynamics-The Case of China
}

\author{
Ruhe Xie ${ }^{1}$, Sisi Han ${ }^{2 *}$, Yuhan Jiang ${ }^{2}$, Zhongren Peng ${ }^{3}$ \\ ${ }^{1}$ School of Management, Guangzhou University, Guangzhou, China \\ ${ }^{2}$ Marquette University, Milwaukee, WI, USA \\ ${ }^{3}$ University of Florida, Gainesville, FL, USA \\ Email: ^rhxie@gzhu.edu.cn, *sisi.han@marquette.edu, yuhan.jiang@marquette.edu, zpeng@ufl.edu
}

How to cite this paper: Xie, R.H., Han, S.S., Jiang, Y.H. and Peng, Z.R. (2018) Comparison and Optimization of Circulation Modes of Fresh Agricultural Products Based on System Dynamics-The Case of China. Journal of Service Science and Management, 11, 297-322.

https://doi.org/10.4236/jssm.2018.113021

Received: April 11, 2018

Accepted: June 8, 2018

Published: June 11, 2018

Copyright (ㅇ 2018 by authors and Scientific Research Publishing Inc. This work is licensed under the Creative Commons Attribution International License (CC BY 4.0).

http://creativecommons.org/licenses/by/4.0/

\begin{abstract}
High efficient circulation of fresh agricultural products plays a significant role in national new urbanization construction. To enhance the stability and improve the efficiency of the supply of fresh agricultural products in urban, this paper constructed a system dynamics model of regional circulation of fresh agricultural products to quantitatively evaluate the efficiency of the six types of circulation modes, based on the SWOT analysis of wholesale market mode, agricultural leading enterprise mode, third party logistics mode, E-commerce mode, super market docking mode, and farmer direct selling mode. The WT-optimization strategy was simulated through overcoming their own shortcomings and coping with external challenges. The results showed the circulation efficiency rank of fresh agricultural products: wholesale market mode $=$ farmer direct selling mode $>$ farm-supermarket docking mode $>$ agricultural leading enterprise mode $>$ E-commerce mode $>$ third party logistics mode, and on the optimization strategy aspect, the supply efficiency of fresh agricultural products would be developed through reducing the delay of procurement and enhancing the ability of sales and procurement efficiently.
\end{abstract}

\section{Keywords}

Circulation of Fresh Agricultural Products, Optimization Strategy, System Dynamics, SWOT

\section{Introduction}

In recent years, the government has attached great importance to the construction of a fresh agricultural product circulation system and the top-level design of 
fresh agricultural products circulation has been perfected. In 2014, the No.1 Document of China government "Several Opinions on Deepening Rural Reform and Accelerating Agricultural Modernization" focused on promoting fair trade in agricultural products and improving circulation and efficiency of the system construction; In 2011, the document of "The State Council on strengthening the construction of fresh agricultural products circulation system" requested to speed up the circulation planning guidance and the cultivation of circulation subject, to strengthen the circulation infrastructure. On the other hand, the mode of circulation system of raw agricultural products needs to be further optimized. After a long period of development, the overall pattern of circulation has been basically formed in China with the leading wholesale market mode as the dominant one, agricultural leading enterprise mode, third party logistics mode, E-commerce mode, farm-supermarket docking mode, farmer direct selling mode and other distribution modes developing together [1] [2] [3]. However, the new urbanization strategy of the country sets new demands on the circulation of fresh agricultural products, that is, to establish an agile, efficient and green circulation system of fresh agricultural products.

Shi \& Zhang [4] analyzed the importance of agricultural logistics and the requirements of the product, the current problems in circulation. They put forward some suggestions for the circulation of agricultural products in China, such as improving the circulation of agricultural products raised on government support and guidance, improving the degree of organization of agricultural production and circulation, increasing infrastructure investment, carrying out agricultural supermarket-docking and focusing on the extent of agricultural information technology optimization strategy. But this paper has not carried out any quantitative analysis.

Loeper et al. [5] pointed that smallholder farmers struggle to take part in modern agricultural value chains in South Africa. They used "system dynamics modelling to understand the dynamics relating to agricultural value-chain participants, and to answer the question as to which value-chain participants potentially have the largest impact on smallholder farmers. The modelling results showed that banks might have the potential to trigger an impact on smallholder farmers' productivity. Smallholder farmers could become a long-term viable and sustainable option for increasing food security in South Africa". However, the model assumed that each of the variables equally influenced smallholder farmers' productivity, yet the reality might very well be different and weights might need to be added to each of the variables in order to represent a more realistic scenario.

Wang and Chen [6] investigated the management decisions via option contracts in a two-stage supply chain in which a fresh produce supplier sold products to a retailer, considering the circulation loss of the fresh produce. They proposed a Stackelberg model to analyze the decisions of supply chain members in the decentralized supply chain compared with the integrated one under the 
newsvendor framework. They found that "there was a unique optimal option order quantity for the retailer and a unique optimal option order price for the supplier giving certain conditions; Furthermore, option contracts cannot coordinate the fresh produce". But the paper has not given a practical example or numerical calculation.

Bao et al. [7] proposed a strategy of supply chain management based on E-commerce service platform for fruits and vegetables. They designed and implemented an architecture and function composing of the service platform which was constructed on a set of application service modules. "The application service modules can be chosen and defined by user, and can be integrated as an application service package and applied as management information system of business process. With the E-commerce service platform, the supply chain management for agreement based circulation of agricultural products of vegetables and fruits can be implemented." But the paper has not discussed the feasibility and reality of the platform.

Webera and Schwaningerb [8] took a typical example of a small to medium-sized enterprise (SME) as an example. They searched for possible ways to sustain the viability of a division of SME in the future. They built a system dynamics (SD) model as a decision support tool for the organization of the distribution system. The results showed that "the modeling and simulation activities undertaken has a trigger function in the process by inducing organizational learning at a very fast pace". But the study is just based on the qualitative investigation and the results mainly depend on the subjective assessment of the participants.

Piewthongngam et al. [9] developed a system dynamics model as a tool for managers to visualize the movement of the entire pig production supply chain. This tool enabled the integration of important factors at each breeding level of fattening pigs. They also applied the tool to a case to explore the mechanism of the model. But the model can be only used in similar livestock supply chain, and the parameters in different supply chain are different.

At present, the circulation modes of fresh agricultural products dominated by circulation entities have been widely recognized, such as the mode of "super market docking" with supermarket chains as the core, the third-party logistics mode with the third-party logistics enterprises as the core. In this case, it is feasible to replace the circulation mode efficiency by the circulation subject efficiency.

According to the present literature, because of the complexity of circulation of fresh agricultural products, we can find that most researches mainly focused on qualitative or theoretical analysis, or some typical supply chain. There is a lack of comprehensive appraisements and judgements to the efficiency of different circulation modes of fresh agricultural products.

High efficient circulation of fresh agricultural products plays a significant role in national new urbanization construction, can improve the stability of the mar- 
ket price of fresh agricultural products and increase the income of farmers. We want to know what mode has the most efficiency in what circumstance. We also want to know how to increase the efficiency of different circulation modes and circulation subjects. Based on the qualitative analysis and evaluation of SWOT, this paper constructs the relevant value of the circulation subject to get the function, and carries on a system dynamics simulation. According to the simulation result, it analyzes the deficiency of various circulation subjects and the circulation pattern. It also validates the effectiveness of the strategy of optimizing circulation of fresh produce in SWOT analysis.

\section{The SWOT Analysis of Fresh Agricultural Products Circulation Modes}

\subsection{Selection of SWOT Analysis Indicators}

Circulation efficiency is the ratio of the trade interest gained in the circulation of commodities to its share and cost [10]. Among them, the expenditures include transportation fee, storage fee, transaction fee and time cost. In view of the perishability and vulnerability of fresh agricultural produce, the circulation loss and shortening of the circulation time are also emphasized [11] [12]. In this paper, the S (Strength) and W (Weakness) in the SWOT analysis consider the input-output relationship between the circulation (cost) input and circulation (utility) output of fresh agricultural products under different modes of circulation of fresh agricultural products [12] [13]. Among them: 1) Circulation costs include: transaction costs and time costs (purchase delay) of fresh agricultural products in circulation mode as reflected by the number of circulation links; logistics and storage costs of fresh agricultural products in circulation mode reflected by logistics costs and circulation losses, and finally brought together in the selling price of fresh produce [14] [15]. 2) Circulation effects include the purchasing ability of fresh agricultural products in the circulation mode reflected by the size of the circulation and the length of the circulating distance; the sales ability (or destocking capability) of the fresh agricultural products in circulation mode reflected by the number of circulation terminals [16] [17].

\subsection{Assignment of SWOT Analysis Index}

In order to facilitate the comparison, the SWOT analysis not only makes a qualitative comparison analysis of the circulation modes of fresh produce, but also quantifies the cost effectiveness and effectiveness of the circulation modes according to Table 1 . The cost effect and effectiveness evaluation of the circulation model corresponding to various kinds of circulation subjects are detailed in Tables 2-7. The assignments of internal abilities are calculated according to the group discussion and expert's consultation.

\subsection{SWOT Analysis and Optimization Strategy}

1) The model of fresh agricultural products wholesale market is currently the 
largest circulation mode of fresh agricultural products, applicable to all types of fresh agricultural products circulation. But there are many circulation links, and many circulation subjects involved, which do not conducive to the realization of the whole process of cold chain transportation. Therefore, the circulation

Table 1. SWOT analysis index and assignment description.

\begin{tabular}{ccccccc}
\hline \multirow{2}{*}{ Index } & Property & \multicolumn{5}{c}{ Assignment instructions } \\
\cline { 3 - 7 } & & 1 & 2 & 3 & 4 & 5 \\
\hline Circulation scale & Utility model & Smallest & Smaller & Moderate & larger & Largest \\
Circulation distance & Utility model & Shortest & Shorter & Moderate & Longer & Longest \\
Circulation terminal & Utility model & Least & Less & Moderate & More & Most \\
Circulation link & Cost type & Most & More & Moderate & Less & Least \\
Logistics cost & Cost type & Highest & higher & Moderate & Lower & Lowest \\
Circulation loss & Cost type & Highest & higher & Moderate & Less & Least \\
\hline
\end{tabular}

*Assignment has been done, the value of the table are as big as possible, the greater the value of circulation, the greater the utility, or the less the circulation costs.

Table 2. Fresh agricultural products wholesale market model SWOT analysis.

\begin{tabular}{|c|c|c|}
\hline Internal ability & Strength & Weakness \\
\hline (assignment) & Circulation scale largest (5); & Circulation Links most (1); \\
\hline \multirow[b]{2}{*}{ External factors } & Circulation distance longest (5); & Logistics costs highest (1); \\
\hline & Distribution terminal most (5); & Circulation loss highest (1); \\
\hline Opportunities & SO strategy & WO strategy \\
\hline National key construction & $\begin{array}{l}\text { Promote the financial reform of } \\
\text { fresh agricultural products }\end{array}$ & $\begin{array}{l}\text { Strengthen the construction of cold } \\
\text { chain facilities in the wholesale } \\
\text { market }\end{array}$ \\
\hline Threats & ST strategy & WT strategy \\
\hline $\begin{array}{l}\text { Impacted by other } \\
\text { modes of circulation }\end{array}$ & $\begin{array}{l}\text { Improve the wholesale market } \\
\text { management mode }\end{array}$ & $\begin{array}{c}\text { Simplify wholesale market fees and } \\
\text { entry procedures }\end{array}$ \\
\hline
\end{tabular}

Table 3. Fresh agricultural products leading enterprise model SWOT analysis.

\begin{tabular}{|c|c|c|}
\hline $\begin{array}{r}\text { Internal ability } \\
\text { (assignment) }\end{array}$ & $\begin{array}{c}\text { Strength } \\
\text { Circulation scale larger (4); } \\
\text { Circulation distance longer (4); } \\
\text { Distribution terminal most (5); }\end{array}$ & $\begin{array}{c}\text { Weakness } \\
\text { Circulation Links more (2); } \\
\text { Logistics costs higher (2); } \\
\text { Circulation loss higher (2); }\end{array}$ \\
\hline Opportunities & SO strategy & WO strategy \\
\hline $\begin{array}{l}\text { The key support of the } \\
\text { state agriculture }\end{array}$ & $\begin{array}{l}\text { Deep (refined) processing } \\
\text { of fresh produce }\end{array}$ & $\begin{array}{l}\text { Developing high-end products and } \\
\text { widening sales channels }\end{array}$ \\
\hline Threats & ST strategy & WT strategy \\
\hline $\begin{array}{l}\text { Affected by agricultural } \\
\text { natural disasters }\end{array}$ & $\begin{array}{l}\text { Provide farmers with seed } \\
\text { and technical support }\end{array}$ & $\begin{array}{l}\text { To provide customized production } \\
\text { and processing services }\end{array}$ \\
\hline
\end{tabular}


Table 4. Fresh agricultural produce third-party logistics SWOT analysis.

\begin{tabular}{|c|c|c|}
\hline & Strength & Weakness \\
\hline (assignment) & $\begin{array}{l}\text { Circulation scale moderate (3); } \\
\text { Circulation distance moderate (3); } \\
\text { Distribution terminal more (4); }\end{array}$ & $\begin{array}{l}\text { Circulation Links moderate (3); } \\
\text { Logistics costs moderate (3); } \\
\text { Circulation loss moderate (3); }\end{array}$ \\
\hline Opportunities & SO strategy & WO strategy \\
\hline $\begin{array}{l}\text { National and logistics industry } \\
\text { strongly advocated }\end{array}$ & $\begin{array}{c}\text { Signed a large number of fresh } \\
\text { agricultural products purchase } \\
\text { orders }\end{array}$ & $\begin{array}{l}\text { Establish the whole process of } \\
\text { cold chain logistics system }\end{array}$ \\
\hline Threats & ST strategy & WT strategy \\
\hline $\begin{array}{l}\text { Social cognitive bias; cold } \\
\text { chain technology is weak }\end{array}$ & $\begin{array}{l}\text { Advocacy of the entire process of } \\
\text { cold chain logistics advantages }\end{array}$ & $\begin{array}{l}\text { Establish agile regional cold } \\
\text { chain logistics center }\end{array}$ \\
\hline
\end{tabular}

Table 5. Fresh agricultural produce e-commerce model SWOT analysis.

\begin{tabular}{|c|c|c|}
\hline Internal ability & Strength & Weakness \\
\hline External factors & $\begin{array}{l}\text { Circulation Links less (4); } \\
\text { Logistics costs lower (4); } \\
\text { Circulation loss less (4); }\end{array}$ & $\begin{array}{c}\text { Circulation scale smaller (2); } \\
\text { Circulation distance shorter (2); } \\
\text { Distribution terminal moderate (3); }\end{array}$ \\
\hline Opportunities & SO strategy & WO strategy \\
\hline $\begin{array}{l}\text { Online shopping, mobile shopping } \\
\text { rise }\end{array}$ & $\begin{array}{l}\text { Develop a stable customer } \\
\text { base with membership } \\
\text { benefits }\end{array}$ & $\begin{array}{l}\text { At the same time carry out online } \\
\text { and offline business }\end{array}$ \\
\hline Threats & ST strategy & WT strategy \\
\hline $\begin{array}{l}\text { Rely on express delivery and cold } \\
\text { chain logistics companies to } \\
\text { participate }\end{array}$ & $\begin{array}{l}\text { Signed a distribution and } \\
\text { reverse logistics service } \\
\text { contract }\end{array}$ & $\begin{array}{l}\text { Self-built stores to complete the last } \\
\text { mile distribution }\end{array}$ \\
\hline
\end{tabular}

Table 6. SWOT analysis of "farm-supermarket docking" mode.

\begin{tabular}{|c|c|c|}
\hline Internal ability & Strength & Weakness \\
\hline External factors & $\begin{array}{l}\text { Circulation Links least (5); } \\
\text { Logistics costs lower (4); } \\
\text { Circulation loss least (5); }\end{array}$ & $\begin{array}{l}\text { Circulation scale smaller (2); } \\
\text { Circulation distance shorter (2); } \\
\text { Distribution terminal least (1); }\end{array}$ \\
\hline Opportunities & SO strategy & WO strategy \\
\hline $\begin{array}{c}\text { National vigorously promote; } \\
\text { supermarket location advantages; }\end{array}$ & $\begin{array}{c}\text { Appropriate discount pricing } \\
\text { strategy }\end{array}$ & $\begin{array}{l}\text { Increase the number of } \\
\text { agricultural products directly } \\
\text { supermarkets }\end{array}$ \\
\hline Threats & ST strategy & WT strategy \\
\hline $\begin{array}{l}\text { Community retail stores and } \\
\text { farmers market impact }\end{array}$ & $\begin{array}{c}\text { The main fresh produce } \\
\text { quality and safety }\end{array}$ & $\begin{array}{l}\text { Large supermarket to join the } \\
\text { community supermarket }\end{array}$ \\
\hline
\end{tabular}

process can easily lead to great loss of fresh produce. The future development of the wholesale market is to strengthen the future trading function of fresh produce, to share the purchase price information [18] [19] [20], and to simplify the 
Table 7. SWOT analysis of "farmer direct sales" model.

\begin{tabular}{|c|c|c|}
\hline Internal ability & Strength & Weakness \\
\hline External factors & $\begin{array}{l}\text { Circulation Links least (5); } \\
\text { Logistics costs lowest (5); } \\
\text { Circulation loss least (5); }\end{array}$ & $\begin{array}{l}\text { Circulation scale smallest (1); } \\
\text { Circulation distance shortest (1); } \\
\text { Distribution terminal least (1); }\end{array}$ \\
\hline Opportunities & SO strategy & WO strategy \\
\hline $\begin{array}{l}\text { Urban residents prefer native } \\
\text { products }\end{array}$ & $\begin{array}{c}\text { Increase the farmers market } \\
\text { characteristics of product } \\
\text { stalls }\end{array}$ & $\begin{array}{l}\text { Participate in agricultural } \\
\text { cooperatives }\end{array}$ \\
\hline Threats & ST strategy & WT strategy \\
\hline $\begin{array}{l}\text { Big cities are limited; food safety } \\
\text { issues }\end{array}$ & $\begin{array}{l}\text { The establishment of farmer } \\
\text { fresh produce quarantine } \\
\text { mechanism }\end{array}$ & Brand development \\
\hline
\end{tabular}

import and export formalities in the wholesale market.

2) Fresh agricultural products leading enterprise model is suitable for high-end fresh agricultural products circulation. Leading enterprises are located in the front of the industrial chain, with a large number of fresh agricultural products breeding technology and fresh agricultural products processing technology. In the future, the leading enterprises have the ability to customized production and processing of fresh agricultural products according to the demand of the market.

3) The third-party logistics model of fresh agricultural products is suitable for the circulation of fresh agricultural products under various storage conditions. The third-party logistics enterprises not only act as the wholesale market of origin but also take the function of the wholesale market, greatly reducing the circulation of fresh produce. It is very suitable for the development of fresh produce from the production to sales of the whole process of cold chain logistics in the future [21], and the establishment of agile regional cold chain logistics center.

4) The e-commerce model of fresh agricultural products is suitable for the circulation of fresh agricultural products with short storage time. Fruits and fresh dairy products are more accepted by the public at this stage. In the future, e-commerce is an important bridge linking agricultural markets in urban and rural areas [22] and should speed up the construction of community self-raising outlets, creating fresh produce delivery format [21].

5) Fresh agricultural products "agricultural super docking" mode is suitable for circulation of leafy vegetables, fruit vegetables and other vegetables, litchi, longan and other fruits, live fish, live shrimp and other aquatic products, and chilled chicken, cold meat and other meat and milk; It is also suitable for circulation of long-stored root vegetables, stem vegetables and other vegetables, and citrus fruits, bananas, pineapples and other fruits; Currently urban residents usually exclude frozen meat products, in the future supermarket chains should construct transparent fresh produce supply chain information system [23], and expand the sales of radiation area. 
6) Farmers direct marketing model for fresh agricultural products is suitable for circulation of a small amount of leafy vegetables, fruit vegetables and other vegetables, lychees, longan and other fruits, live fish, live shrimp and other aquatic products, and live chickens, live ducks and other poultry; In the future it should focus on the development of branding agriculture and agricultural cooperatives [24] [25].

In short, it is urgent to optimize the purchasing and logistics transportation links of fresh agricultural products wholesale market, leading enterprise mode and third-party logistics mode so as to reduce procurement delay, and to optimize the sales links of e-commerce mode, "farm-supermarket docking mode" and farmer direct selling mode to reduce circulation costs such as inventory loss, thereby enhancing the supply efficiency of fresh agricultural products.

\section{The System Dynamics Modeling of Regional Fresh Agricultural Products Distribution}

\subsection{Hypothesis of Regional Fresh Produce Circulation SD Model Border}

According to the requirements of system dynamics, in order to accurately describe its causal relationship and change law without losing generality, we should first clear the basic boundary of the circulation of fresh agricultural products, including the source of agricultural products, circulation subjects, demand and its change, circulation loss and delay.

Boundary 1: Suppose the supply of fresh agricultural products in the region is divided into two parts: the fresh agricultural products produced in the region and the fresh agricultural products purchased from outside the region.

Boundary 2: Suppose that fresh agricultural products outside the region with longer circulation distances are procured by the fresh agricultural products wholesale markets, leading enterprises and third-party logistics enterprises.

Boundary 3: Suppose that fresh agricultural products in the region with shorter circulation distances are sold by the fresh agricultural e-commerce enterprises, large-scale supermarket chains and farmer households.

Boundary 4: Suppose that the demand for fresh produce in the region consists of two parts: one is the demand for basic fresh produce (a fixed quantity) and the other is the demand for high-end fresh produce (variable and cyclical).

Boundary 5: Suppose that when fresh agricultural products in the region cannot meet the demand, procurement outside the region increases and outflow in the region reduces.

Boundary 6: Suppose that there are different circulation losses [26] and delays in the distribution of fresh agricultural products.

\subsection{The SD Causal Feedback Loop of Regional Fresh Produce Circulation}

According to the above six regional agricultural products circulation model 
boundary, using Vensim PLE to draw a causal feedback loop shown in Figure 1.

In Figure 1, the sign " + " means that the factors in the beginning of blue arrows have positive influence to the factors in the end of the arrows; the sign "-" means that the factors in the beginning of red arrows have negative influence to the factors in the end of the arrows. For example, the more the supply gap of fresh agro-products, the higher the market unit price of fresh agro-products will be, but the less the outflow of fresh agro-products.

This model is applicable to those areas where the total output of fresh agricultural products is less than the total demand, and some characteristic fresh agricultural products in the region (such as Guangdong's litchi and longan) are also exported outwards. Among them, the main reason for the variable tree is as follows:

1) Fresh produce comes from outside and within the region (Figure 2), respectively, in line with the SD model boundary 1 to 3 limitation.

2) The demand for fresh produce includes the demand for basic fresh produce and high-end fresh produce (Figure 3 ). The demand for high-end produce is affected by the price of fresh produce and it is in line with the limits of SD boundary model 4.

3) The supply of fresh agricultural products wholesale market is subject to the

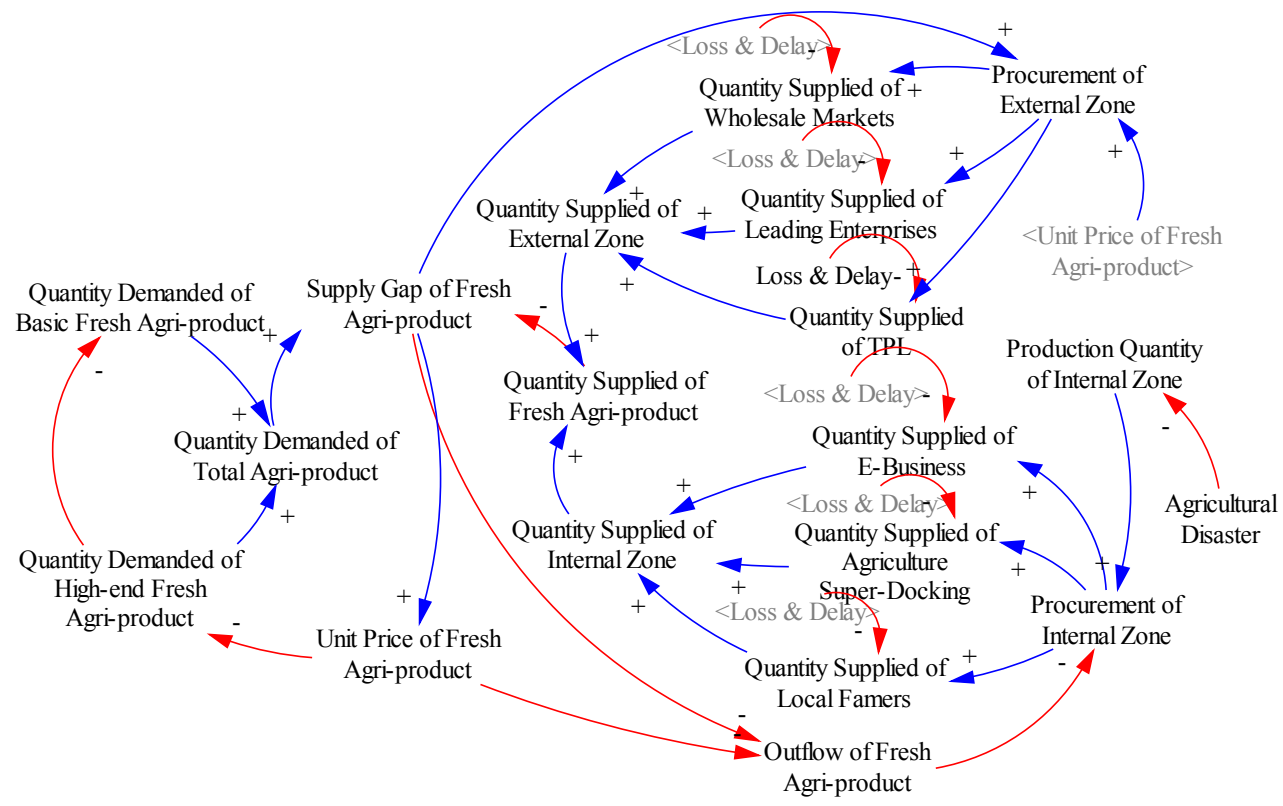

Figure 1. The SD causal feedback loop of regional fresh produce circulation.

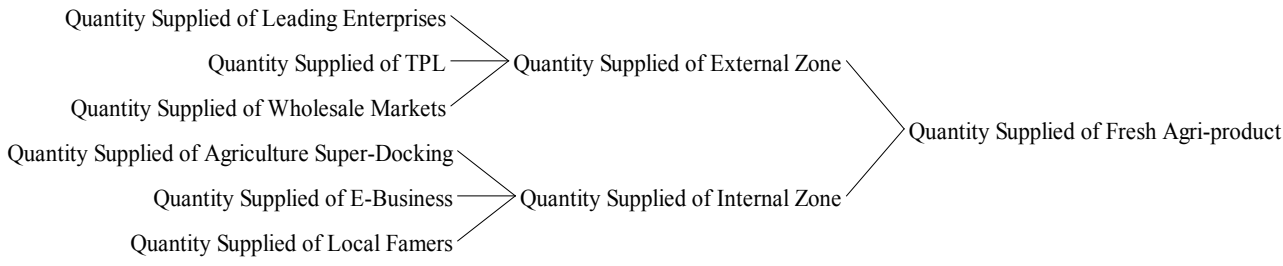

Figure 2. Fresh produce supply reason tree. 
(Quantity Demanded of High-end Fresh Agri-product) —— Quantity Demanded of Basic Fresh Agri-product Unit Price of Fresh Agri-product — Quantity Demanded of High-end Fresh Agri-product

Figure 3. Demand for fresh produce tree.

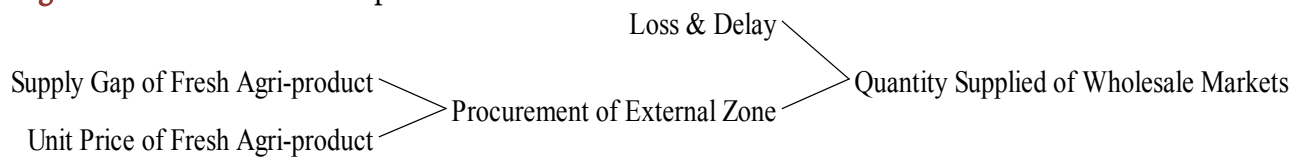

Figure 4. Wholesale market supply reason tree.

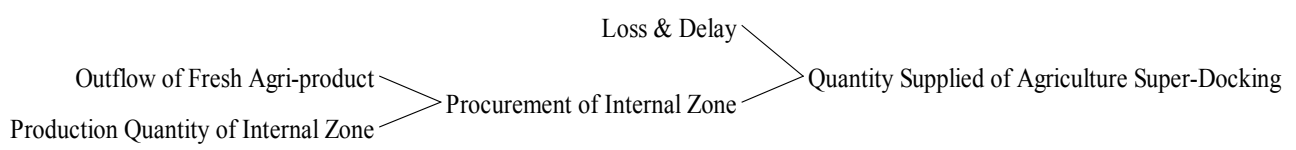

Figure 5. Large supermarket chains supply tree.

limitation of purchase volume, circulation loss and procurement delay (Figure 4), qualifying the boundary 6 of the SD model. The quantity of procurement outside the region is affected by the gap of fresh agricultural products and meets the definition of SD model boundary 5 .

4) The supply of fresh produce in large supermarket chains is affected by the output, outflow quantity, circulation loss and purchase delay of fresh agricultural products in the region (Figure 5). And it meets the boundaries of the SD model boundary 3,5 , and 6 .

\subsection{The SD Flow Chart of Regional Fresh Agricultural Products Circulation and the Relationship between Variables}

Based on the SD model boundary and the SD causal feedback loop diagram, a dynamical flow chart of the regional fresh agricultural product circulation system is constructed based on the dominant circulation sector instead of the circulation mode (Figure 6).

There are six state variables in the model, including wholesale market inventory, leading enterprise inventory, third-party logistics inventory, e-commerce inventory, supermarket inventory and farmer direct sales inventory. The rate variable is 12 , which are 1 to 5 and self-retention (representing the purchasing capacity of fresh agricultural products of 6 main circulation entities), 1 to 6 for sale (sales capacity of fresh agricultural products representing 6 main circulation entities), 8 auxiliary variables, and $s 1$ to $s 6$ for the loss rate of inventory. Circulation variables and functions are listed in Table 8.

\section{Comparison of the Efficiency of Fresh Agricultural Products Circulation Modes}

\subsection{Model Scenario Hypothesis}

Take a town of 500,000people as a research object.

The initial parameters of the model setting: Start time $=0$, End time $=38$ days, Simulation step size $=1$ day, as Figure 7 shows.

Scenario 1: The demand of fresh agricultural products shows a periodical var- 
iation of the sine function: $5+\operatorname{Sin}\left(\right.$ Time $\left.{ }^{*} 3.14 / 4\right)$ (Cycle period of 8 days, the range of [4] [6] kg/day). The demand for basic fresh agricultural products remains unchanged at 700,000 kg/day Estimates by Chinese daily fresh foods consumption from the dietary guidelines, by $1.4 \mathrm{~kg} /$ person), as show in Figure 7 .

Scenario 2: The initial inventory of all main subject of circulation is the upper limit of their purchasing power, as shown in Table 9.

Scenario 3: There is no delay in steady supply of fresh agricultural products by farmers every day, as shown in Table 9.

Scenario 4: The maximum inventory loss rate of fresh agricultural products wholesale market is $20 \%$ /day, as shown in Table 9.

\subsection{Assignment of Model Variables}

The SWOT analysis in Tables 2-7 have assigned the circulation utility index and cost index of 6 types of fresh agricultural products circulation mode. On this basis, Formulas 1 to 4 assign a value to calculate the purchasing, sales, delay and loss attributes of all main subject of circulation, where:

1) Procurement capacity. The purchasing power of circulation of fresh agricultural products is mainly reflected in two aspects: the scope of the procurement of

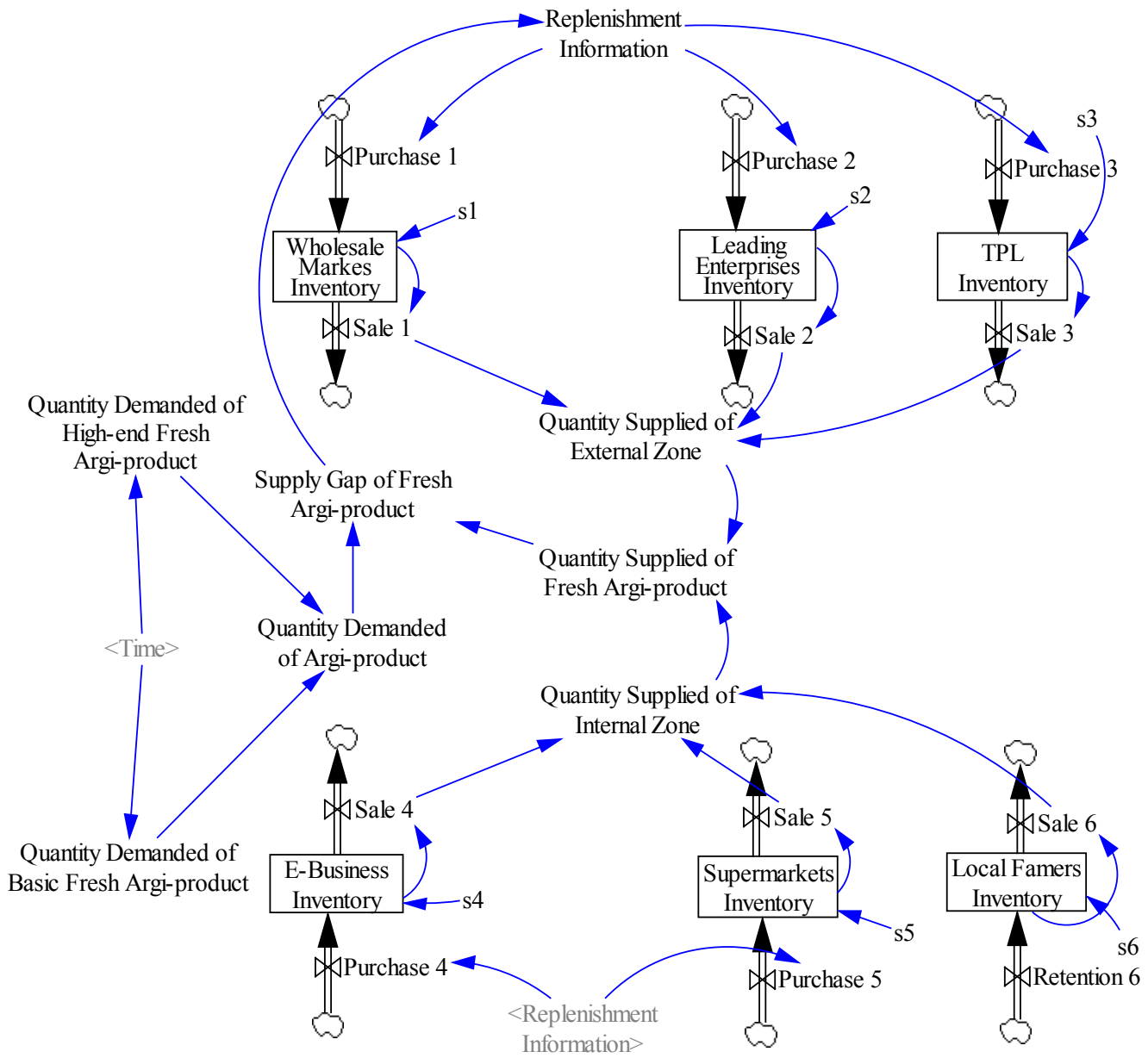

Figure 6. Regional fresh produce circulation system dynamics flow chart. 
Table 8. Variables function relationship.

\begin{tabular}{|c|c|c|c|}
\hline Variable name & Attribute & Expression & Unit \\
\hline Wholesale inventory & Status & INTEG $(($ Purchase $1-$ Sell 1$) *(1-$ s1 $)$, initial value $)$ & Unit amount \\
\hline Leading enterprise inventory & Status & INTEG $(($ Purchase $2-$ Sell 2$) *(1-s 1)$, initial value $)$ & Unit amount \\
\hline Third-party logistics inventory & Status & INTEG $(($ Purchase $3-$ Sell 3$) *(1-$ s1 $)$, initial value $)$ & Unit amount \\
\hline E-commerce inventory & Status & INTEG $(($ Purchase $4-$ Sell 4$) *(1-s 1)$, initial value $)$ & Unit amount \\
\hline supermarket inventory & Status & INTEG $(($ Purchase $5-$ Sell 5$) *(1-s 1)$, initial value $)$ & Unit amount \\
\hline Farmers direct inventory & Status & INTEG $(($ Stay 6 - Sell 6$) *(1-s 6)$, initial value $)$ & Unit amount \\
\hline Sell 1 & Rate & $\begin{array}{l}\text { IF THEN ELSE (Wholesale Market Inventory > Sales Capability, Sales } \\
\text { Capability, Wholesale Market Inventory) }\end{array}$ & Unit amount/day \\
\hline Sell 2 & Rate & $\begin{array}{l}\text { IF THEN ELSE (Leading Enterprise Stock }>\text { Sales Capability, Sales } \\
\text { Capability, Leading Enterprise Stock) }\end{array}$ & Unit amount/day \\
\hline Sell 3 & Rate & $\begin{array}{l}\text { IF THEN ELSE (third-party logistics inventory > sales ability, sales ability, } \\
\text { third-party logistics inventory) }\end{array}$ & Unit amount/day \\
\hline Sell 4 & Rate & $\begin{array}{l}\text { IF THEN ELSE (e-commerce inventory > sales, sales, e-commerce } \\
\text { inventory) }\end{array}$ & Unit amount/day \\
\hline Sell 5 & Rate & $\begin{array}{l}\text { IF THEN ELSE (supermarket chain inventory > sales ability, sales ability, } \\
\text { supermarket chain inventory) }\end{array}$ & Unit amount/day \\
\hline Sell 6 & Rate & $\begin{array}{l}\text { IF THEN ELSE (Farmers direct sales inventory > sales ability, sales ability, } \\
\text { farmers direct inventory) }\end{array}$ & Unit amount/day \\
\hline Purchase 1 & Rate & $\begin{array}{l}\text { IF THEN ELSE (Replenishment Information }=1 \text {, DELAY3 (Replenishment } \\
\text { Information * Purchasing Capability, Purchase Delay), 0) }\end{array}$ & Unit amount/day \\
\hline Purchase 2 & Rate & $\begin{array}{l}\text { IF THEN ELSE (Replenishment Information }=1 \text {, DELAY3 (Replenishment } \\
\text { Information * Purchasing Capability, Purchase Delay), 0) }\end{array}$ & Unit amount/day \\
\hline Purchase 3 & Rate & $\begin{array}{l}\text { IF THEN ELSE (Replenishment Information }=1 \text {, DELAY3 (Replenishment } \\
\text { Information * Purchasing Capability, Purchase Delay), 0) }\end{array}$ & Unit amount/day \\
\hline Purchase 4 & Rate & $\begin{array}{l}\text { IF THEN ELSE (Replenishment Information }=1 \text {, DELAY1 (Replenishment } \\
\text { Information * Purchasing Capability, Purchase Delay), 0) }\end{array}$ & Unit amount/day \\
\hline Purchase 5 & Rate & $\begin{array}{l}\text { IF THEN ELSE (Replenishment Information }=1 \text {, DELAY1 (Replenishment } \\
\text { Information * Purchasing Capability, Purchase Delay), 0) }\end{array}$ & Unit amount/day \\
\hline Stay 6 & Rate & The number of stay & Unit amount/day \\
\hline Regional supply & Auxiliary & For Sale $4+$ For Sale $5+$ For Sale 6 & Unit amount/day \\
\hline Out-of-area supply & Auxiliary & For Sale $1+$ For Sale $2+$ For Sale 3 & Unit amount/day \\
\hline Fresh produce supply & Auxiliary & Regional supply + supply outside the region & Unit amount \\
\hline Fresh produce gap & Auxiliary & Fresh produce demand - fresh produce supply & Unit amount \\
\hline Demand for fresh produce & Auxiliary & High-end fresh produce demand + basic fresh produce demand & Unit amount \\
\hline Basic fresh produce demand & Auxiliary & WITH LOOKUP (Time, table function) & Unit amount \\
\hline High-end fresh produce demand & Auxiliary & Fixed demand + changing demand & Unit amount \\
\hline Replenishment information & Auxiliary & IF THEN ELSE (Fresh Produce Gap $\geq 1,1,0$ ) & None \\
\hline
\end{tabular}




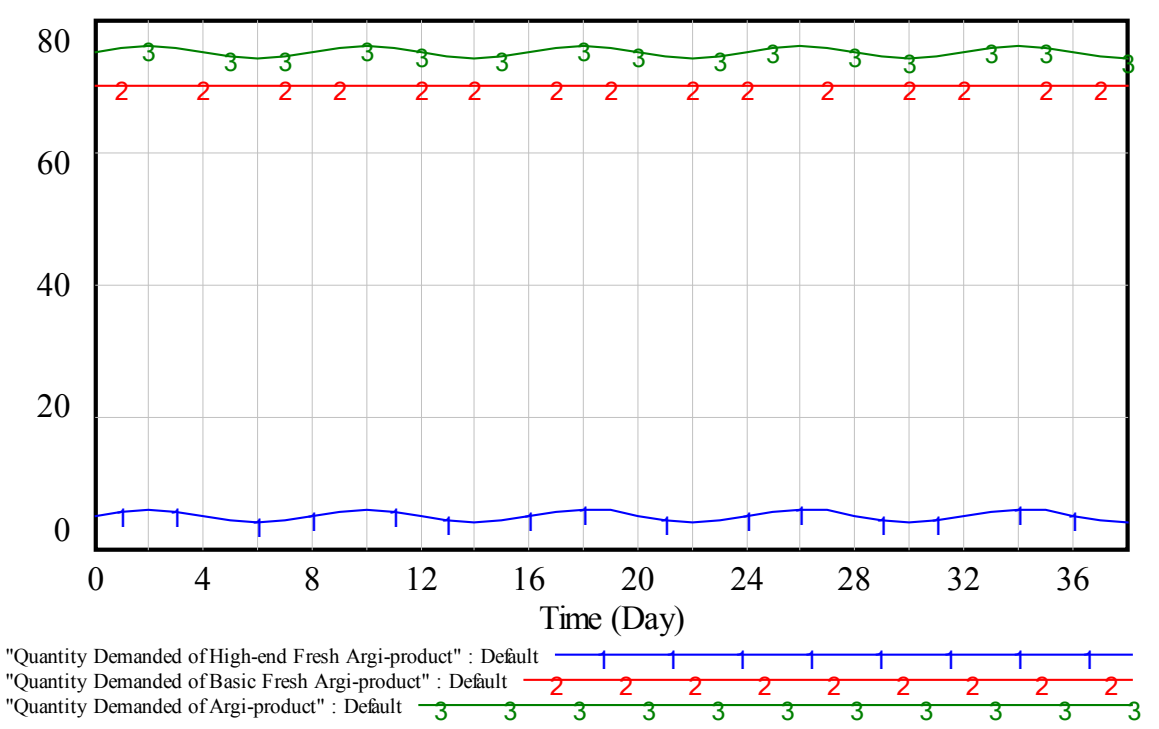

Figure 7. Demand for fresh agricultural products during the simulation period.

Table 9. State variable initial value and constant value.

\begin{tabular}{cccccc}
\hline $\begin{array}{c}\text { Main subject of } \\
\text { circulation }\end{array}$ & $\begin{array}{c}\text { Initial inventory } \\
\text { value } \\
(10,000 \mathrm{~kg})\end{array}$ & $\begin{array}{c}\text { Sales capacity } \\
(10,000 \\
\mathrm{kg} / \text { day })\end{array}$ & $\begin{array}{c}\text { Purchasing } \\
\text { capacity } \\
(10,000 \mathrm{~kg} / \text { day })\end{array}$ & $\begin{array}{c}\text { Procurement } \\
\text { delay }\end{array}$ & $\begin{array}{c}\text { Inventory } \\
\text { loss } \\
(\% / \text { day })\end{array}$ \\
\hline Wholesale market & 25 & 21 & 25 & 5 & 20 \\
Leading enterprise & 20 & 22 & 20 & 4 & 10 \\
Third party logistics & 15 & 19 & 15 & 3 & 7 \\
E-commerce & 10 & 16 & 10 & 2 & 5 \\
Farm-supermarket & 10 & 8 & 10 & 1 & 4 \\
docking & 5 & 9 & 5 & 0 & 4 \\
farmer direct selling & & & & & \\
\hline
\end{tabular}

fresh agricultural products range and the capacity of fresh agricultural products procurement. Therefore, circulation size and distance constitute a procurement capacity index. In this index, circulation distance $\times 4$ represents the purchasing power of fresh agricultural products of main subject of circulation in the four geographical location in the east, south, north, circulation size represents the purchasing capacity of fresh agricultural products purchased by main subject of circulation in a purchase.

Procurement capacity $=$ Circulation distance $\times 4+$ Circulation size $(1)$

2) Marketing capacity. Fresh agricultural products circulation main sales (inventory) ability mainly is reflected in two aspects. One is the price of fresh agricultural products, the other one is the number of fresh agricultural products sales (shipping). Therefore, distribution terminals and logistics costs constitute the sales ability index, among them: Circulation Terminal $\times 4$ Representative Sales Capacity of fresh agricultural products on 4 Geographical Directions of East, West, North and South, Logistics cost attributes actually show the price of 
fresh agricultural products attractive to consumers the size.

Marketing capacity $=$ circulation terminal $\times 4+$ logistics costs

3) Purchasing delay. The purchase delay of fresh agricultural products circulation sector is reflected in two aspects: the collection of fresh agricultural products procurement information on the delay and the fresh agricultural products from the origin to the sale of goods in the process of transportation delay. Therefore, circulation constitutes a procurement delay indicator. Namely, $6 \mathrm{mi}$ nus the circulation of the main indicators of the circulation value from 1 to 5 to assign the value of circulation ascending order of the bulk of fresh agricultural products procurement delay from short and long.

$$
\text { Purchasing delay }=6-\text { Circulation time }
$$

4) Stock loss. Loss in the circulation of fresh agricultural products is reflected in two aspects: the loss of transport and the loss of the storage process. Therefore, loss in circulation constitutes inventory loss indicator. Namely, corresponding inventory loss of $20 \%$ /day to the circulation subject with the smallest circulation loss, the inventory loss value of other circulation subjects is calculated by formula (4). The circulation of the relative size of the loss converted to the circulation of the main inventory loss value.

$$
\text { Inventory loss }=20 \% \times(\min \{\text { circulation loss }\} / \text { circulation loss } i)
$$

The values of the attributes in Tables 2-8 are brought into Equations (1)-(4) to calculate the sales ability, purchasing power, purchase delay, and inventory loss value of each fresh agricultural product circulation entity (Table 9).

\subsection{Analysis of Simulation Results}

Run Vensim PLE, the simulation results are listed as below (Figures 8-12).

After one cycle of fresh agricultural products demand (1 - 8 days), the supply

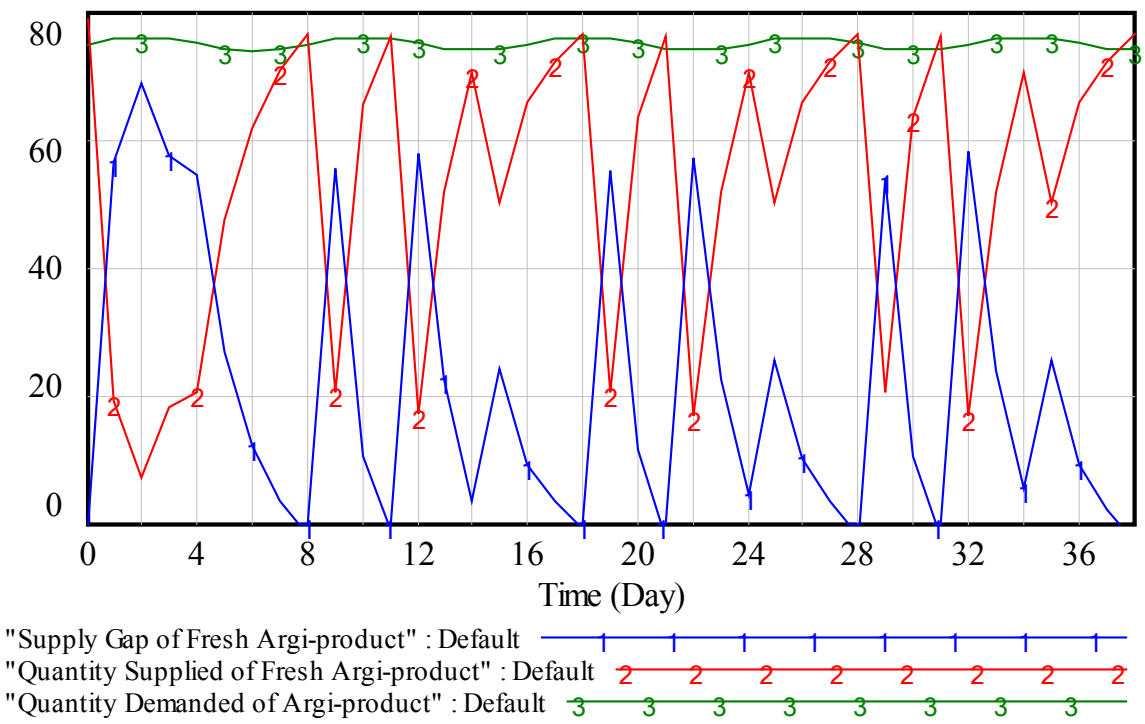

Figure 8 . The supply and demand of fresh produce in the simulation period. 


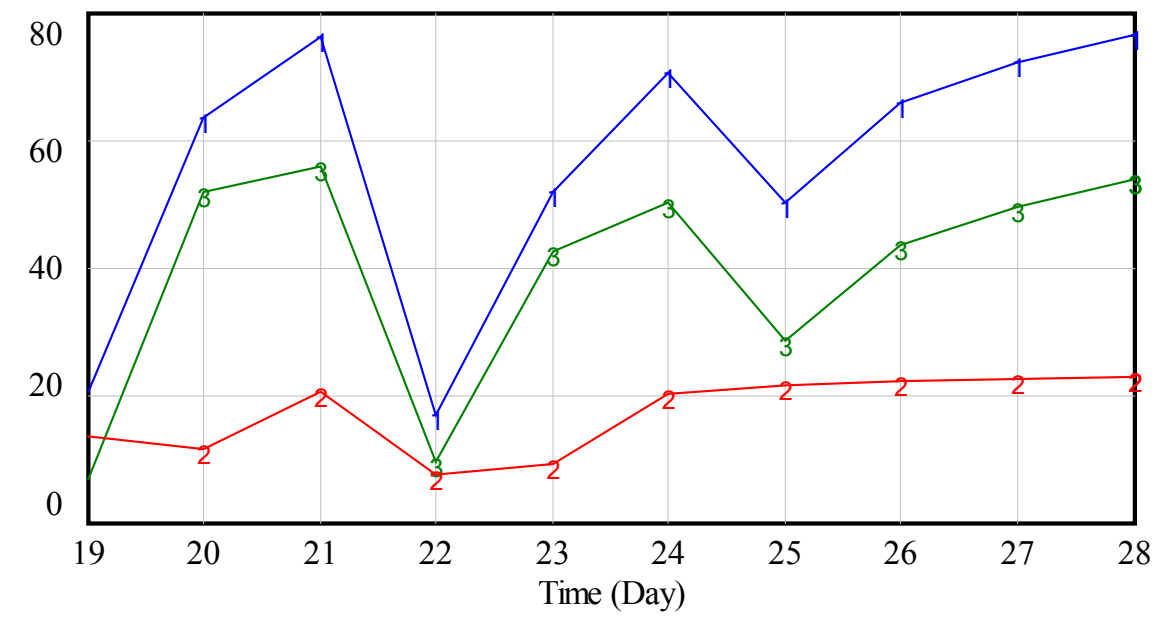

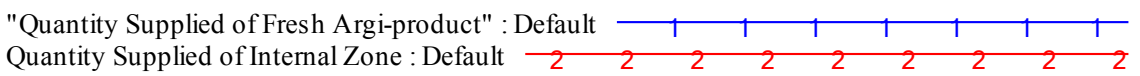

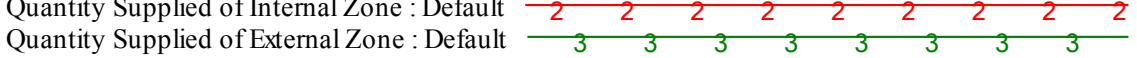

Figure 9. The supply of fresh produce in one period.
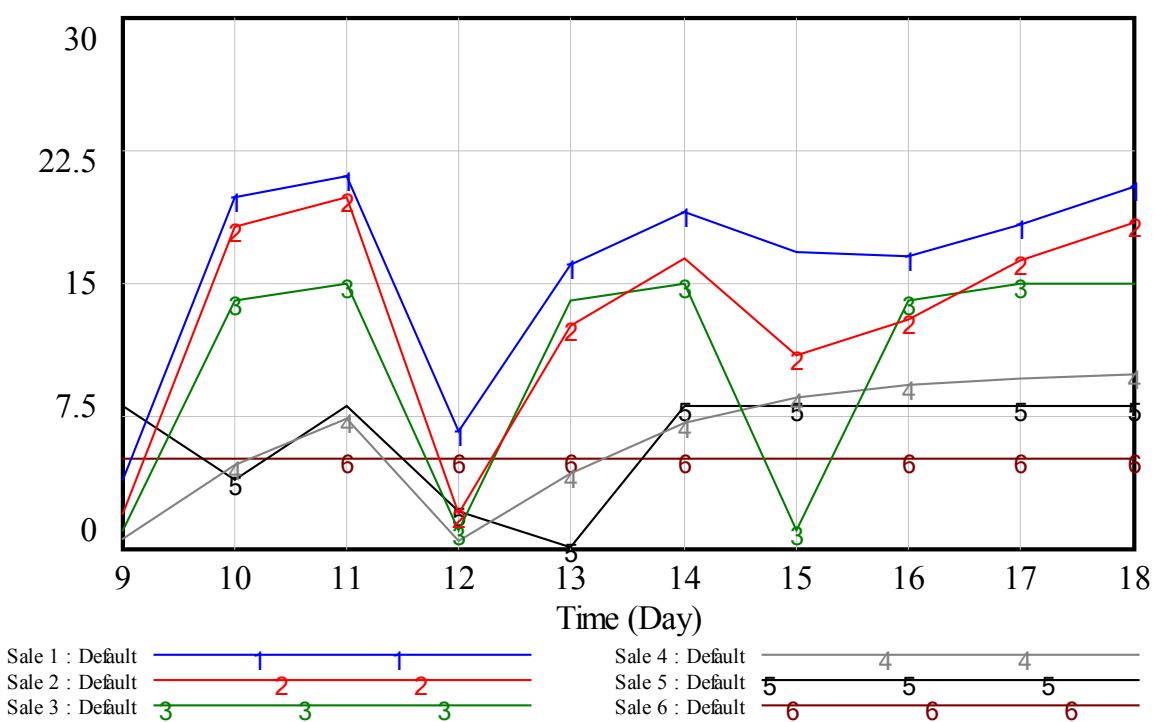

\begin{tabular}{|c|c|c|c|c|c|}
\hline & Main subject of circulation & The total cycle & Mean & Standard deviation & Variable coefficient \\
\hline sell 1 & wholesale market & 158.15 & 15.82 & 5.83 & 0.37 \\
\hline sell 2 & leading enterprise & 129.18 & 12.92 & 6.44 & 0.50 \\
\hline sell 3 & third party logistics & 105.00 & 10.50 & 6.54 & 0.62 \\
\hline sell 4 & E-commerce & 61.36 & 6.14 & 3.56 & 0.58 \\
\hline sell 5 & Farm-supermarket docking & 62.00 & 6.20 & 3.03 & 0.49 \\
\hline sell 6 & farmer direct selling & 50.00 & 5.00 & 0.00 & 0.00 \\
\hline
\end{tabular}

Figure 10. The sale of fresh produce for each circulation subject.

of fresh agricultural products and the gap of fresh agricultural products fluctuate periodically with the period of 10 days. In the day of $9^{\text {th }}$ to $18^{\text {th }}, 19^{\text {th }}$ to $28^{\text {th }}$, and $29^{\text {th }}$ to $38^{\text {th }}$, there are 3 fluctuation cycles. 

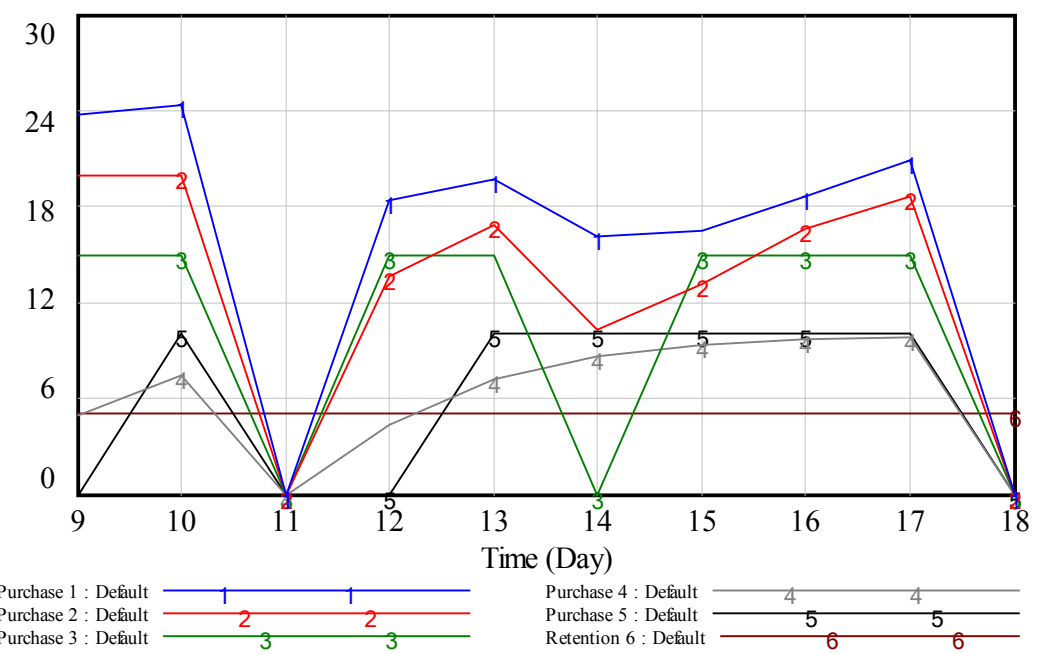

Purchase 3 : Default 3 3 3 Retention

\begin{tabular}{lllllll}
\hline & Main subject of circulation & Maximum & $\begin{array}{l}\text { Gross } \\
\text { purchases }\end{array}$ & Mean & $\begin{array}{l}\text { Standard } \\
\text { deviation }\end{array}$ & $\begin{array}{l}\text { Variable } \\
\text { coefficient }\end{array}$ \\
\hline purchase 1 & Wholesale market & 24.37 & 158.36 & 15.84 & 8.78 & 0.55 \\
purchase 2 & Leading enterprise & 19.97 & 129.10 & 12.91 & 7.47 & 0.58 \\
purchase 3 & Third party logistics & 15.00 & 105.00 & 10.50 & 7.25 & 0.69 \\
purchase 4 & E-commerce & 9.82 & 61.36 & 6.14 & 3.72 & 0.61 \\
purchase 5 & Farm-supermarket docking & 10.00 & 60.00 & 6.00 & 5.16 & 0.86 \\
purchase 6 & farmer direct selling & 5.00 & 50.00 & 5.00 & 0.00 & 0.00
\end{tabular}

Figure 11. The purchasing situation of fresh produce of each circulation subject.
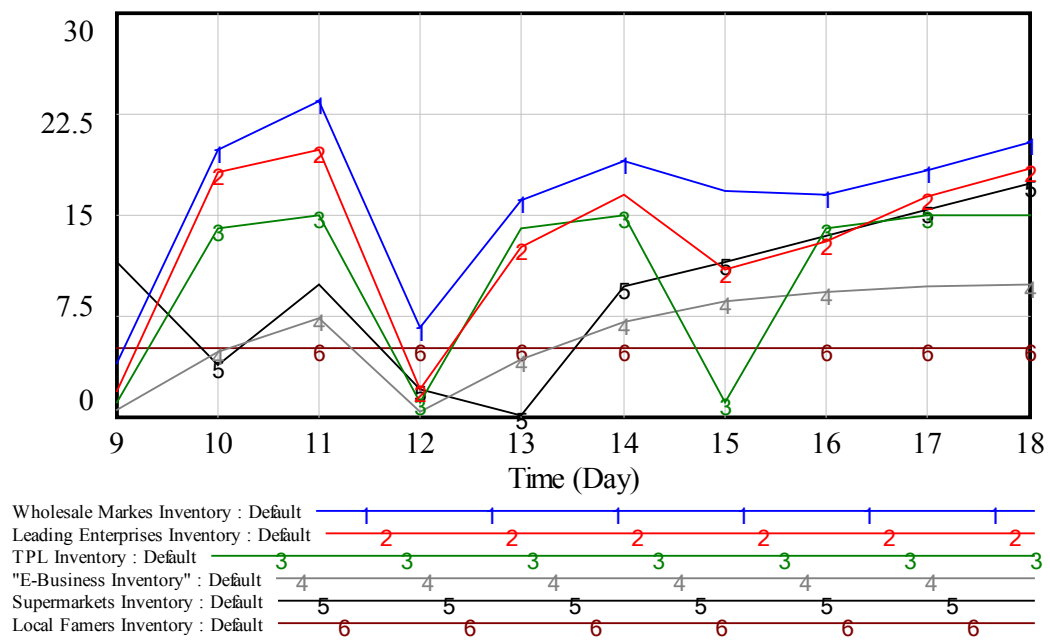

\begin{tabular}{llllll}
\hline Main subject of circulation & Maximum & Total & Mean & Sale & Rate \\
\hline Wholesale market & 23.46 & 160.61 & 16.06 & 21.00 & 0.76 \\
Leading enterprise & 19.79 & 129.18 & 12.92 & 22.00 & 0.59 \\
Third party logistics & 15.00 & 105.00 & 10.50 & 19.00 & 0.55 \\
E-commerce & 9.81 & 61.36 & 6.14 & 16.00 & 0.38 \\
Super market docking & 17.28 & 94.49 & 9.45 & 8.00 & 1.18 \\
Farmer direct selling & 5.00 & 50.00 & 5.00 & 9.00 & 0.56
\end{tabular}

Figure 12. Inventory of different market in one cycle. 
Fresh agricultural product supply and demand cycle (e.g., $9^{\text {th }}$ to $18^{\text {th }}$ days) is 10 days; the full supply of fresh agricultural products fully effective (fresh produce supply on the day $>$ demand) for 2 days (20\%), basic fresh agricultural products effective supply (Same day fresh agricultural products supply $>$ basic fresh agricultural products demand) for 4 days (40\%), fresh agricultural products supply is invalid for 6 days. The average gap of fresh agricultural products is 18.60 days, the standard deviation is 21.77 , and the coefficient of variation is 1.17 .

Within one cycle, the supply of fresh agricultural products in the region is relatively stable while the supply of fresh agricultural products outside the region varies greatly. This is caused by the delay in the procurement of wholesale markets, leading enterprises and third-party logistics which is consistent with the weaknesses in the circulation process as pointed out in the SWOT analysis.

Wholesale market mode in one cycle has the largest number of fresh agricultural products for sale. The quantity of sales is: Wholesale Market $>$ Leading enterprises $>$ Third-party logistics $>$ Chain stores $>$ E-commerce $>$ Farmers direct marketing. From the perspective of coefficient of variation, because delay isn't considered, farmer direct sales is the minimum degree of variation. Consider the procurement delay of the five circulation patterns, although the wholesale market model procurement delay of up to 5 days, the sale of fresh agricultural products is the most stable. Wholesale Markets $>$ Supermarkets $>$ Leading Enterprises $>$ E-commerce $>$ Third-party Logistics.

Wholesale market mode in one cycle purchases the largest number of fresh agricultural products, namely, wholesale market $>$ Leading enterprises $>$ Third-party logistics $>$ E-commerce $>$ Farm-Supermarket docking $>$ Farmers direct sale. From the perspective of coefficient of variation, because delay is not considered, farmer direct sales is the minimum degree of variation. Consider the procurement delay of the five circulation patterns, although the wholesale market model procurement delay of up to 5 days, the purchase of fresh agricultural products is the most stable export markets: Leading Enterprises $>$ E-commerce $>$ Third-party Logistics $>$ Farm-supermarket docking. Among them, supermarket chain and third-party logistics appears in 4 days and 3 days, respectively. They did not purchase more than the other two circulation entities which did not purchase the case, increasing its inventory management requirements.

5) In one cycle, the number of fresh agricultural products stored in the chain supermarket mode is the most adequate to fully meet the needs of its normal sales (with surplus), Farm-Supermarket docking $>$ Wholesale Market $>$ Leading Enterprise $>$ Direct Marketing of Farmers $>$ Third-Party Logistics $>$ E-commerce. From the opposite perspective, e-commerce inventory is the smallest, which means that its inventory management has obvious advantages (Figure 12).

\subsection{Model Test}

The results of system dynamics simulation and AHP evaluation are compared to verify the validity and accuracy of the model. AHP hierarchy model and evalua- 
tion results are shown in Figure 13, in which: the target layer is efficiency of main subject of circulation of fresh agricultural products; the guideline layer includes two factors of utility and cost; the sub-criteria layer includes the circulation scale, circulation distance, circulation terminal, circulation, logistics costs, circulation losses; program layer, including six kinds of fresh agricultural products circulation mode. It is assumed that the elements of the criteria and sub-criteria are of equal importance. The judgment matrix and consistency test of the criterion layer and sub-criterion layer are omitted. The relative advantage is calculated by using the difference of attribute values of each circulation pattern For example, if the scale of the wholesale market circulation is 5 and the circulation scale of the third party logistics is 3 , the difference between the two is 2 , then the degree of advantage of the wholesale market relative to the third party logistics on the circulation scale is 5 , as shown in Table 10.

The efficiency of circulation of AHP evaluation results ranked as follows: Wholesale Market (0.2273) > Farmers Direct (0.1992) > Farm-supermarket docking (0.1709) > Leading Enterprises (0.1643) > E-commerce (0.1232) > Third Party Logistics (0.1151). The AHP evaluation results further verified the accuracy of the stable (effective) distribution of fresh produce in the simulation results of the system dynamics model (considering the purchase delay): Wholesale market, supermarket chain, leading enterprise, e-commerce, third-party logistics. Therefore, the constructed regional SD model of fresh agricultural products is effective and can be used to compare the efficiency of the circulation mode of fresh agricultural products.

Table 10. Attribute values and relative importance conversion of circulation pattern.

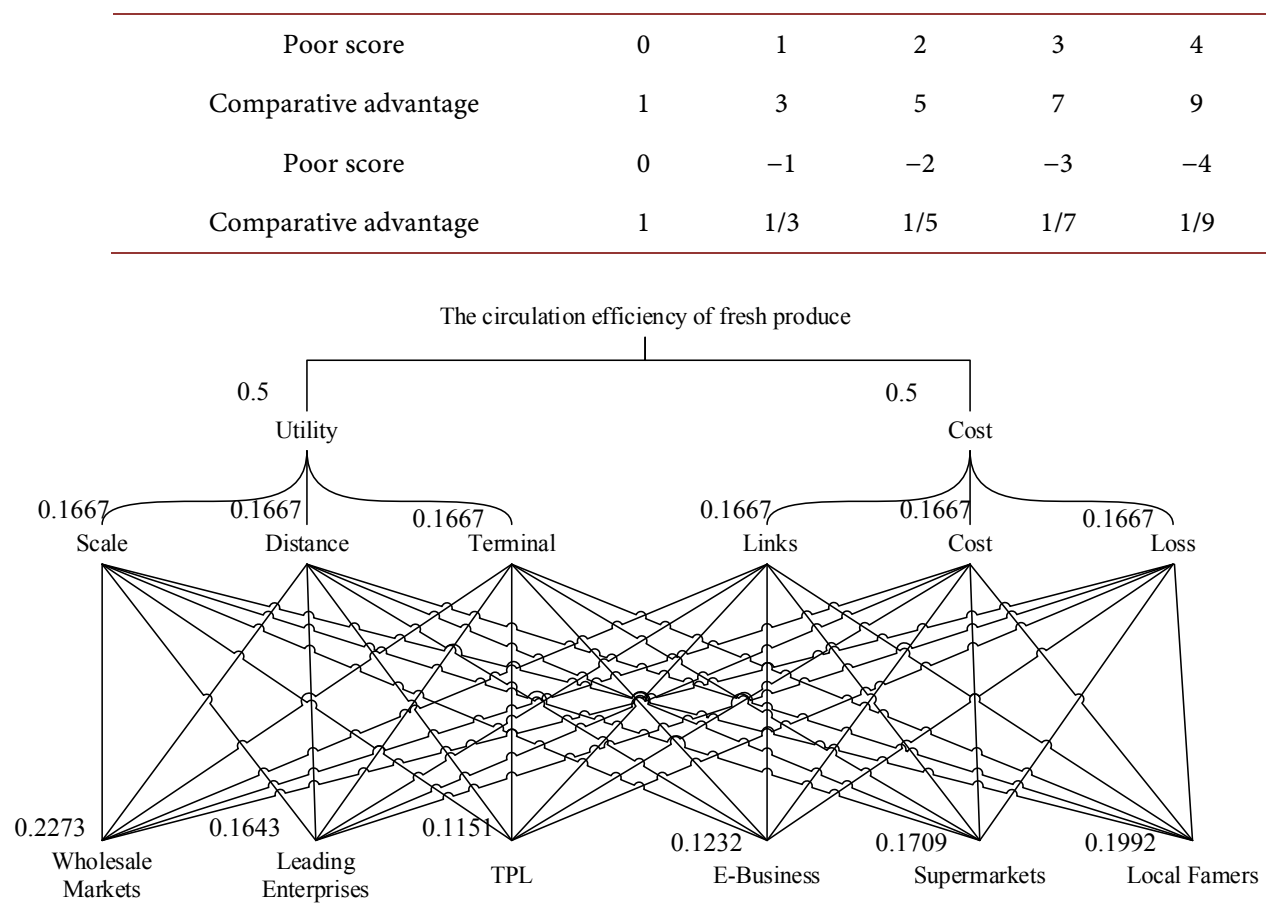

Figure 13. AHP evaluation results of the efficiency of fresh products circulation. 
We can conclude that the most efficient and stable supply of fresh agricultural products is the wholesale market model and farmer direct selling mode, followed by "farm-supermarket docking mode", leading enterprise model, e-commerce model, and then, the third-party logistics model. This verifies that the government vigorously building the "public welfare" agricultural products wholesale market is correct. Agricultural products wholesale market in the coming period has an irreplaceable role [27]. At the same time, we should also re-examine the important role of farmers in direct marketing of fresh agricultural products.

\section{Simulation and Analysis of Optimization Strategy of Fresh Agricultural Products Circulation}

SWOT analysis has proposed SO, WO, ST and WT optimization strategies for six types of circulation modes. Among them, WT strategy is the strategy of circulation mode of fresh agricultural products to overcome its own inferiority to deal with external challenges. The simulation of WT strategy is as follows.

\subsection{Simulation and Analysis of Purchasing Delay Optimization Strategy}

To effectively enhance the procurement of fresh agricultural products, logistics and transport efficiency, and to reduce procurement delays, SWOT analysis WT strategy for the wholesale market model simplifies the wholesale market charges and out of formalities. The WT strategy of the leading enterprise model provides customized production and processing services. The WT strategy of the tripartite logistics model establishes an agile regional cold chain logistics center. In order to test the effectiveness of these optimization strategies, a strategic simulation is proceeded to study on the wholesale market model with the longest delay in procurement.

- Optimization Strategy Scenario Assumptions

1) The default value for wholesale purchase delay is 5 (days) for the "initial state" of the simulation;

2) Delay in the procurement of the wholesale market is adjusted to 4 (days) and 3 (days) to simulate two levels of optimization strategies: "enhancing logistics efficiency" and "enhancing logistics efficiency +2 ".

- Optimization Strategy Simulation Results and Analysis

1) After applying WT optimization strategy (Figure 14), the fluctuation trend of "fresh produce gap" remained basically unchanged, but shifted to the left by 1 day and 2 days (enhancing logistics efficiency) respectively. The decrease of procurement delay from the WT optimization strategy put fresh agricultural products into the market ahead of schedule The amount of "fresh agricultural products gap" decreased in one cycle, and "improvement of logistics efficiency" and "improvement of logistics efficiency +2 " decreased by 3.06, 8.72 units of fresh agricultural products, the reduction of post-optimization procurement of WT has increased the number of fresh agricultural products circulating in the wholesale market. 
2) The total amount of fresh agricultural products for sale in the wholesale market increased in 1 cycle after applying the WT optimization strategy (Figure 15), with an increase of 3.06 and 12.85 units respectively compared with the

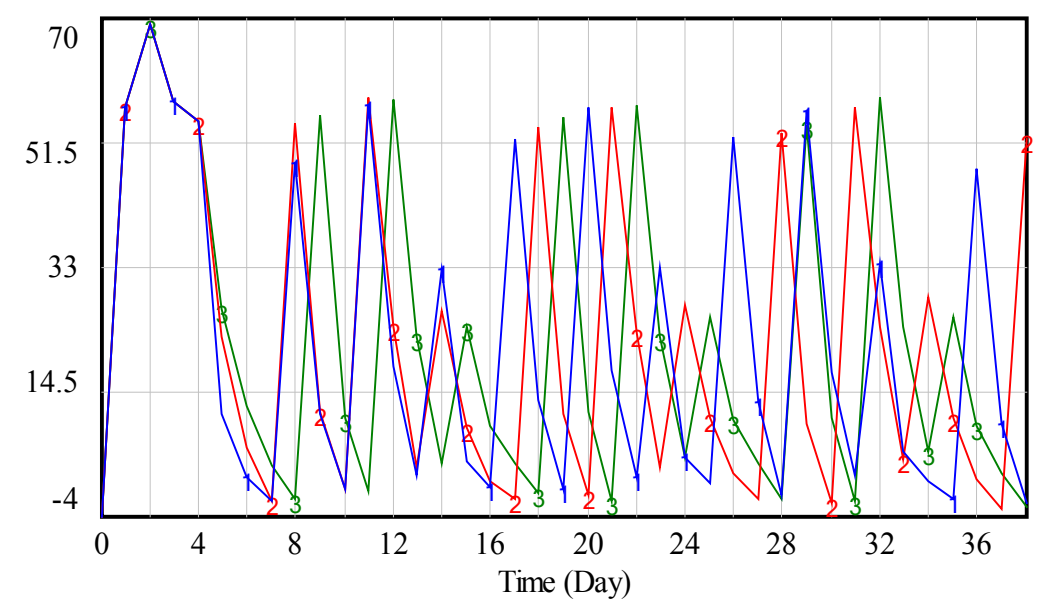

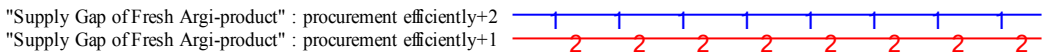

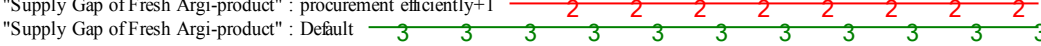

\begin{tabular}{|c|c|c|c|c|c|c|c|c|c|c|c|c|c|c|}
\hline & 19 & 20 & 21 & 22 & 23 & 24 & 25 & 26 & 27 & 28 & Total & Mean & $\begin{array}{l}\text { standard } \\
\text { deviation }\end{array}$ & $\begin{array}{c}\text { variable } \\
\text { coefficient }\end{array}$ \\
\hline logistics +2 & -0.15 & 6.70 & 17.55 & 1.64 & 32.87 & 4.77 & 0.85 & 52.16 & 12.99 & -0.85 & 178.54 & 17.85 & 21.94 & 1.23 \\
\hline logistics +1 & 11.03 & -1.01 & 56.58 & 23.10 & 3.06 & 27.36 & 10.45 & 2.28 & -1.49 & 52.83 & 184.19 & 18.42 & 21.42 & 1.16 \\
\hline Begin & 55.26 & 11.55 & -1.72 & 57.02 & 22.52 & 4.64 & 25.60 & 10.30 & 3.65 & -1.57 & 187.25 & 18.73 & 21.71 & 1.16 \\
\hline
\end{tabular}

Figure 14. Improve the logistics efficiency WT strategy fresh produce gap simulation result.

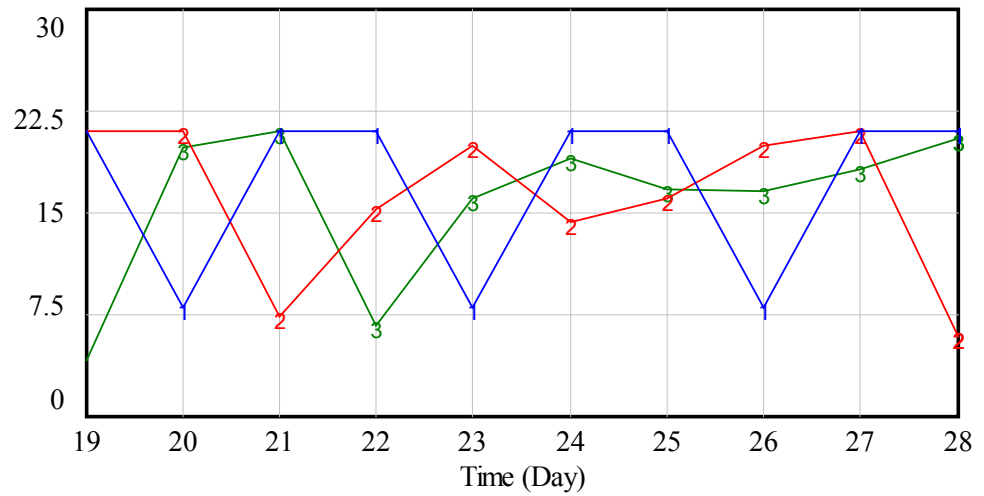

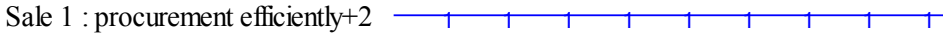

Sale 1 : procurement efficiently $+1 \quad \begin{array}{llllllllll}2 & 2 & 2 & 2 & 2 & 2 & 2 & 2 & 2 & 2\end{array}$

Sale 1 : Default \begin{tabular}{llllllllllll}
\hline & 3 & 3 & 3 & 3 & 3 & 3 & 3 & 3 & 3 & 3 & 3
\end{tabular}

\begin{tabular}{ccccccccccccccc}
\hline & 19 & 20 & 21 & 22 & 23 & 24 & 25 & 26 & 27 & 28 & Total & Mean & $\begin{array}{c}\text { standard } \\
\text { deviation }\end{array}$ & $\begin{array}{c}\text { variable } \\
\text { coefficient }\end{array}$ \\
\hline logistics + 2 & 21.00 & 8.00 & 21.00 & 21.00 & 8.00 & 21.00 & 21.00 & 8.00 & 21.00 & 21.00 & 171.00 & 17.10 & 6.28 & 0.37 \\
logistics + 1 & 20.98 & 21.00 & 7.34 & 15.13 & 19.86 & 14.22 & 16.02 & 19.87 & 21.00 & 5.80 & 161.21 & 16.12 & 5.65 & 0.35 \\
Begin & 4.08 & 19.76 & 21.00 & 6.59 & 15.99 & 18.98 & 16.68 & 16.48 & 18.21 & 20.38 & 158.15 & 15.82 & 5.80 & 0.37 \\
\hline
\end{tabular}

Figure 15. Improve logistics efficiency WT strategy wholesale market to sell simulation results. 
"initial state" in "enhancing logistics efficiency" and "enhancing logistics efficiency +2 ". However, as the degree of optimization increases, the stability of the supply of fresh agricultural products does not increase continuously. The stability of "enhancing the efficiency of logistics" is greater than the supply of fresh agricultural products of "enhancing logistics efficiency +2 " stability (the smaller the coefficient of variation, the more stable the supply of fresh agricultural products in circulation mode).

The simulation results show that the decrease of procurement delay of main circulation subject can increase the effectiveness of fresh agricultural products supply. However, unlimited resources cannot be invested to increase the efficiency of procurement and logistics. The reason is that under certain conditions, the stability of the supply of fresh agricultural products is not continuously improved when the procurement and logistics efficiency are improved.

\subsection{Sales Ability Optimization Strategy Simulation and Analysis}

In order to effectively improve the sales ability of circulation mode, reduce the inventory level, the circulation loss and the circulation cost, the WT strategy of the e-commerce mode finishes the last mile distribution by store. The WT strategy of "farm-supermarket docking" is that the large-scale supermarket win over the community supermarkets to join, and the WT strategies of "farmers direct selling" are brand development. In order to test the effectiveness of these optimization strategies, the strategy simulation research on the "farm-supermarket docking" model with the weakest sales ability is conducted.

- Optimize strategy scenario assumptions.

1) "Farm-supermarket-docking" sales of the default value of 8 (unit volume/day), for the simulation of the "initial state";

2) Adjusted sales ability of Farm-supermarket docking e was 9 (unit quantity/day) and 10 (unit quantity/day) to simulate the two optimization strategies of "improving sales efficiency" and "improving sales efficiency +2 ".

- Optimization strategy simulation results and analysis.

1) There was no overall movement of "fresh agricultural product gap" after applying the WT optimization strategy (Figure 16). The total number of fresh agricultural product gaps did not change in one cycle, indicating that WT optimization strategy cannot increase the quantity of fresh agricultural products circulating through supermarket chains. However, the coefficient of variation for "gap in fresh agricultural products" i.e., the amount of fluctuation in each day, increased.

2) The total amount of fresh agricultural products sold by chain supermarkets after applying WT optimization strategy (Figure 17) remained unchanged in one cycle. Both "improving sales efficiency", "improving sales efficiency +2 " and "initial status" were all 60 units However, as the degree of optimization increases, the daily sales volume of supermarket chains has changed a lot and the stability has been deteriorated (the coefficient of variation has increased). The reason 


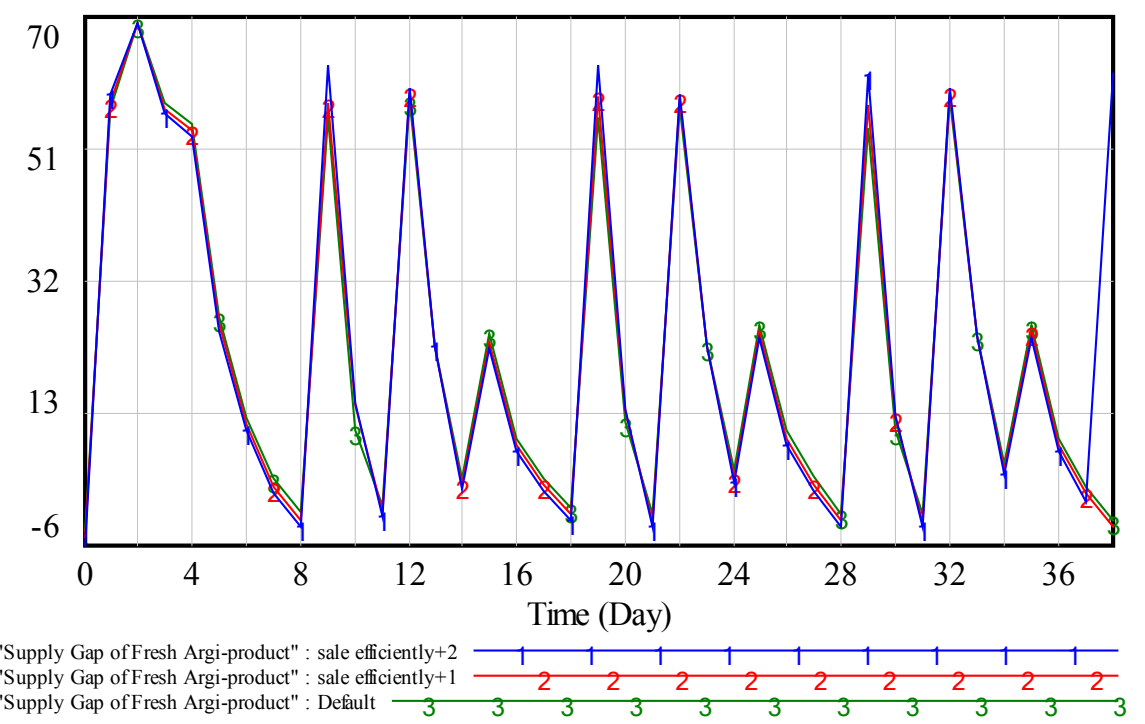

\begin{tabular}{|c|c|c|c|c|c|c|c|c|c|c|c|c|c|c|}
\hline & 19 & 20 & 21 & 22 & 23 & 24 & 25 & 26 & 27 & 28 & Total & Mean & $\begin{array}{l}\text { standard } \\
\text { deviation }\end{array}$ & $\begin{array}{c}\text { variable } \\
\text { coefficient }\end{array}$ \\
\hline sale +2 & 62.86 & 13.45 & -3.32 & 58.64 & 22.59 & 3.04 & 23.62 & 8.30 & 1.65 & -3.57 & 187.25 & 18.73 & 24.12 & 1.29 \\
\hline sale +1 & 58.46 & 13.28 & -2.72 & 58.05 & 22.57 & 3.64 & 24.60 & 9.30 & 2.65 & -2.57 & 187.25 & 18.73 & 22.83 & 1.22 \\
\hline Begin & 55.26 & 11.55 & -1.72 & 57.02 & 22.52 & 4.64 & 25.60 & 10.30 & 3.65 & -1.57 & 187.25 & 18.73 & 21.71 & 1.16 \\
\hline
\end{tabular}

Figure 16. Improve the sales efficiency WT strategy fresh produce gap simulation results.

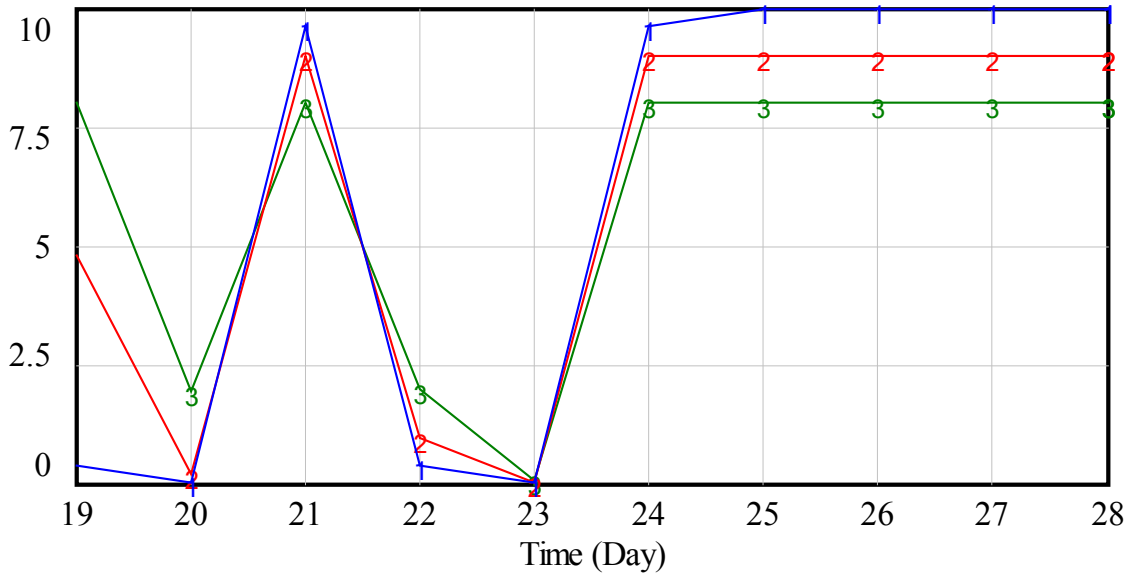

Sale 5 : sale efficiently +2

Sale 5 : sale efficiently+1 $\begin{array}{lllllllllll}2 & 2 & 2 & 2 & 2 & 2 & 2 & 2 & 2 & 2\end{array}$

Sale 5 : Default $\begin{array}{llllllllllll}3 & 3 & 3 & 3 & 3 & 3 & 3 & 3 & 3 & 3 & 3 & 3\end{array}$

\begin{tabular}{|c|c|c|c|c|c|c|c|c|c|c|c|c|c|c|}
\hline & 19 & 20 & 21 & 22 & 23 & 24 & 25 & 26 & 27 & 28 & Total & Mean & $\begin{array}{l}\text { Standard } \\
\text { deviation }\end{array}$ & $\begin{array}{l}\text { Variable } \\
\text { coefficient }\end{array}$ \\
\hline sale +2 & 0.40 & 0.02 & 9.60 & 0.38 & 0.02 & 9.60 & 9.98 & 10.00 & 10.00 & 10.00 & 60.00 & 6.00 & 4.99 & 0.83 \\
\hline sale +1 & 4.80 & 0.19 & 9.00 & 0.97 & 0.04 & 9.00 & 9.00 & 9.00 & 9.00 & 9.00 & 60.00 & 6.00 & 4.08 & 0.68 \\
\hline Begin & 8.00 & 1.92 & 8.00 & 2.00 & 0.08 & 8.00 & 8.00 & 8.00 & 8.00 & 8.00 & 60.00 & 6.00 & 3.26 & 0.54 \\
\hline
\end{tabular}

Figure 17. Improve sales efficiency WT strategy chain supermarket to sell simulation results. 
is that the purchasing power of supermarket chains has not been improved. The total amount of fresh agricultural products circulating has not changed in one cycle.

3) The maximum value of supermarket inventory decreases after applying WT optimization strategy (Figure 18) in 1 cycle. When the supermarket chain's sales ability and purchasing ability are equal ("improving sales efficiency +2 "), the chain store's inventory management is the most effective.

From above analysis, we find that the increase of sales ability of main circulation subject can reduce the inventory quantity, the loss of inventory and the circulation costs. However, enhancing the sales ability alone without enhancing the purchasing power of main circulation subject cannot increase the effective supply of fresh agricultural products. Therefore, all kinds of main circulation subject of fresh agricultural products should strengthen the "lean" management [28] of the circulation of fresh agricultural products and work together to optimize the purchasing power and sales ability of main circulation subject.

\section{Conclusions}

In this paper, the SWOT qualitative analysis and the SD quantitative analysis are integrated in the structural design of the model, and mutual verification is carried out, and the dynamic model of the regional fresh agricultural product circulation system is constructed. From SWOT analysis and system dynamics

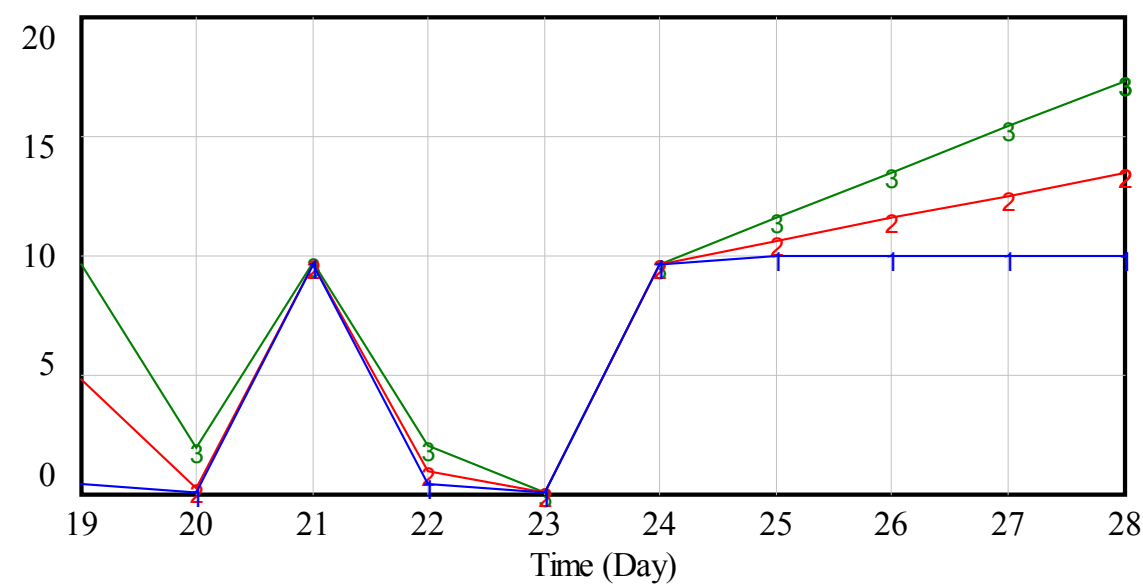

Supermarkets Inventory : sale efficiently +2 r Supermarkets Inventory : sale efficiently+1 $\begin{array}{llllllllll}2 & 2 & 2 & 2 & 2 & 2 & 2 & 2 & 2\end{array}$ Supermarkets Inventory : Default $\begin{array}{llllllllll}3 & 3 & 3 & 3 & 3 & 3 & 3 & 3 & 3\end{array}$

\begin{tabular}{|c|c|c|c|c|c|c|c|c|c|c|c|c|c|c|}
\hline & 19 & 20 & 21 & 22 & 23 & 24 & 25 & 26 & 27 & 28 & Total & Mean & $\begin{array}{l}\text { Standard } \\
\text { deviation }\end{array}$ & $\begin{array}{c}\text { Variable } \\
\text { coefficient }\end{array}$ \\
\hline Sale +2 & 0.40 & 0.02 & 9.60 & 0.38 & 0.02 & 9.60 & 9.98 & 10.00 & 10.00 & 10.00 & 60.00 & 6.00 & 4.99 & 0.83 \\
\hline Sale +1 & 4.80 & 0.19 & 9.61 & 0.97 & 0.04 & 9.60 & 10.56 & 11.52 & 12.48 & 13.44 & 73.22 & 7.32 & 5.30 & 0.72 \\
\hline Begin & 9.60 & 1.92 & 9.68 & 2.00 & 0.08 & 9.60 & 11.52 & 13.44 & 15.36 & 17.28 & 90.50 & 9.05 & 5.92 & 0.65 \\
\hline
\end{tabular}

Figure 18. Improve the sales efficiency WT strategy chain supermarket inventory simulation results. 
simulation of circulation of regional fresh agricultural products, we have the following findings:

1) It is urgent to optimize the purchasing and logistics transportation links of fresh agricultural products' wholesale market, leading enterprise mode and third-party logistics mode so as to reduce procurement delay, and to optimize the sales links of e-commerce mode, "farm-supermarket docking mode" and farmer direct selling mode to reduce circulation costs such as inventory loss, thereby enhancing the supply efficiency of fresh agricultural products.

2) The most efficient and stable supply of fresh agricultural products is the wholesale market model and farmer direct selling mode, followed by "farm-supermarket docking mode", leading enterprise model, e-commerce model, and then, the third-party logistics model. This verifies that the government vigorously building the "public welfare" agricultural products' wholesale market is correct.

3) Decreasing the procurement delay of main circulation subject can increase the effectiveness of fresh agricultural products supply. However, unlimited resources cannot be invested to increase the efficiency of procurement and logistics.

4) Improving the sales ability of main circulation subject can reduce the inventory quantity, the loss of inventory and the circulation costs. However, enhancing the sales ability alone without enhancing the purchasing power of main circulation subject cannot increase the effective supply of fresh agricultural products. Therefore, all kinds of main circulation subject should strengthen "lean" management and work together to optimize the purchasing power and sales ability.

\section{Acknowledgements}

The authors acknowledge hereby the China National Social Science Fund Key Project (14ZDA031), the China National Social Science Fund Project (17BJY102, 15BGL201), the projects (2016B020205004, 2017B090907028, 611138153066) from the Department of Science and Technology of Guangdong province and the China Scholarship Council for supporting the first author's visiting study at the University of Florida for 6 months (10.2017-4.2018).

\section{References}

[1] Zhao, X. and Li, C. (2012) Transformation of Agricultural Products Circulation Channel: Evolution Law, Motive Mechanism and Development Trend. Management World, No. 3, 81-95.

[2] Zhang, L., Wang, N. and Zhao, S. (2013) Study on Household Consumption Behavior and Retail Terminal Layout of Fresh Agricultural Products in Small and Medium-Sized Cities-Taking the Vegetable Retail Terminal in Yantai City of Shandong Province as an Example. Issues in Agricultural Economy, No. 6, 74-81.

[3] Zhou, J. and Shang, J. (2015) Evaluation of the Efficiency of Agricultural Products Circulation in Different Modes. Journal of Anhui Agricultural Sciences, No. 2, 
317-321.

[4] Shi, X. and Zhang, W. (2013) Agricultural Products Circulation Problem Analysis and Optimization of Logistics Operations. 6th International Conference on Information Management, Innovation Management and Industrial Engineering, 123-126.

[5] Loeper, W., Musango, J., Alan, B. and Scott, D. (2016) Analysing Challenges Facing Smallholder Farmers and Conservation Agriculture in South Africa: A System Dynamics Approach. SAJEMS Asset Research NS, 19, 747-773. https://doi.org/10.4102/sajems.v19i5.1588

[6] Wang, C. and Chen, X. (2013) Option Contracts in Fresh Produce Supply Chain with Circulation Loss. Journal of Industrial Engineering and Management, 6, 104-112.

[7] Bao, L., Huang, Y., Ma, Z., Zhang, J. and Lv, Q. (2012) On the Supply Chain Management Supported by E-Commerce Service Platform for Agreement Based Circulation of Fruits and Vegetables. Physics Procedia, 33, 1957-1963.

[8] Webera, M. and Schwaningerb, M. (2002) Transforming an Agricultural Trade Organization: A System-Dynamics-Based Intervention. System Dynamics Review, 18, 381-401.

[9] Piewthongngam, K., Vijitnopparat, P., et al. (2014) System Dynamics Modelling of an Integrated Pig Production Supply Chain. Biosystems Engineering, 127, 24. https://doi.org/10.1016/j.biosystemseng.2014.08.007

[10] Zhang, L., Wang, N. and Tang, X. (2011) Distribution Efficiency of Agricultural Products: Concept Definition and Evaluation Indicators Design. East China Economic Management, No. 4, 18-21.

[11] Xu, Y. and Meng, F. (2009) The Problems and Countermeasures in the Circulation of Beijing Livestock and Poultry Products. Journal of Beijing Technology and Business University (Social Sciences), No. 3, 18-22.

[12] Ren, Y. (2012) Evaluation of Aquatic Products Circulation Efficiency Based on DEA in Si Chuan Province. Southwest Jiao Tong University, Chengdu.

[13] Yang, Y. and Xiao, Q. (2011) Comparative Study on Costs and Efficiency of Circulation of Agricultural Products under Different Circulation Channels-Case Analysis Based on Grape Circulation in Jinzhou. Issues in Agricultural Economy, No. 2, 79-88.

[14] Xu, J. and Li, Z. (2015) Research on the Deconstruction of Circulation Costs of Agricultural Products in China under the Background of Price Excess-A Case Study of Dalian Rapeseed Market. Research on Financial and Economic Issues, No. 6, 93-99.

[15] Shan, Z. (2012) The Gray Correlation Analysis of Agricultural Products Logistics and Its Influence Factors. Systems Engineering, No. 10, 123-126.

[16] Zhu, Y. and Huang, H. (2011) Chinese Agricultural Product Supply Chain Construction Model. China Logistics \& Purchasing, No. 4, 68-69.

[17] Yang, F. (2013) Empirical Analysis on the Impact of Agricultural Products Logistics Capability on Their Circulation Efficiency. Journal of Commercial Economics, No. 30, 38-39.

[18] Dan, B. and Chen, J. (2008) Coordinating Fresh Agricultural Supply Chain under the Valuable Loss. Chinese Journal of Management Science, No. 5, 42-49.

[19] Banker, R., Mitra, S. and Sambamurthy, V. (2011) The Effects of Digital Trading Platforms on Commodity Prices in Agricultural Supply Chains. MIS Quarterly, 35, 
599-611.

[20] Dan, B., Ding, S. and Fu, H. (2013) Fresh Supply Chain Coordination by Wholesale Market in Sale Place under Information Asymmetry. Journal of Management Sciences, No. 10, 40-50.

[21] Wang, H. (2016) Research on the Development of Cold Chain Logistics of Fresh Produce in China. Agricultural Economy, No. 2, 132-133.

[22] Wang, X. and Zhang, Q. (2016) Internal Mechanism for Ecommerce Solving Difficulty in Circulation of Fresh Agricultural Products: A Comparative Double-Case Study of Tmall and Tootoo. China Soft Science, No. 2, 39-55.

[23] Zhou, S., Zhang, Z. and Zhang, Y. (2011) Discussion on Constructing Information Management System of Fresh Produce Supply Chain in Supermarket. Management World, No. 3, 1-6.

[24] Liu, J., Wang, K. and Zhang, C. (2016) Problems with Fresh Agricultural Products E-Commerce and the Countermeasures. China Business and Market, No. 12, 57-64.

[25] Xu, G., Wang, Y. and Wang, C. (2016) Production Mode, Passageway Construction and Fresh Produce Logistics-Taking Sichuan, a Major Inland Agricultural Province as an Example. Rural Economy, No. 8, 78-83.

[26] Wu, Q. (2016) Research on the Delivery System of "Internet plus Fresh Produce" in China. Economic Review, No. 6, 76-79.

[27] Li, Z. and Mi, X. (2017) Economic Analysis on the Lack of Public Welfare in Agricultural Product Wholesale Market. On Economic Problems, No. 1, 110-114.

[28] Taylor, D.H. (2006) Strategic Considerations in the Development of Lean Agri-Food Supply Chains: A Case Study of the UK Pork Sector. Supply Chain Management: An International Journal, 11, 271-280. 